Brit. J. industr. Med., 1959, 16, 148.

\title{
THE VALUE OF MOBILIZATION OF LEAD BY CALCIUM ETHYLENE-DIAMINE-TETRA-ACETATE IN THE DIAGNOSIS OF LEAD POISONING
}

\author{
BY \\ J. TEISINGER and J. SRBOVÁ \\ From the Clinic for Occupational Diseases, Prague, and the Institute of Industrial Hygiene and Occupational \\ Diseases, Prague
}

(RECEIVED FOR PUBLICATION JULY 23, 1958)

\begin{abstract}
Traditional laboratory tests for lead poisoning tend to fail in cases where a considerable interval has elapsed since exposure. We have used calcium ethylene-diamine-tetra-acetate $\left(\mathrm{CaNa}_{2} \mathrm{EDTA}\right)$ for the quantitative mobilization of lead for diagnostic purposes.

In a control group of 50 individuals who had never worked with lead it was found that the average urinary excretion of lead in 24 hours amounted to 0.031 to $0.043 \mathrm{mg}$. The maximum value did not exceed $0.100 \mathrm{mg}$. After intravenous injection of $\mathrm{CaNa}_{2} \mathrm{EDTA}$ the amount of excreted lead rose considerably, but did not exceed $0.350 \mathrm{mg} . / 24 \mathrm{hr}$.

In a group of 47 individuals who had formerly worked with lead or who were still engaged in this work but did not show any symptoms of poisoning, the urinary lead levels before injection were higher than in the control group. After injection of $\mathrm{CaNa}_{2}$ EDTA the lead excretion in 24 hours increased considerably. After injection of $\mathrm{CaNa}_{2} \mathrm{EDTA}$, patients suffering from chronic lead poisoning showed a considerable increase of urinary lead excretion, which attained the order of milligrams in 24 hours.

The fractionated examination of the urine of 10 unexposed individuals, undertaken at intervals of three hours, showed after injection of $\mathrm{CaNa}_{2}$ EDTA no higher lead concentration than 0.500 $\mathrm{mg}$./litre, the highest concentrations being observed six hours after injection. In the urine of individuals exposed to lead or suffering from lead poisoning a higher urinary lead concentration was found than in the control group, and the maximum was in these cases found at various time intervals.

It is concluded that the mobilization of lead may be of considerable value in the diagnosis of atypical cases of chronic lead poisoning, but the results can be evaluated only in association with the general clinical picture.
\end{abstract}

The laboratory tests at present employed for the diagnosis of lead poisoning have proved satisfactory. They fail, however, in cases where exposure is not very severe and particularly when a considerable time has elapsed since termination of exposure. In such cases it may then be difficult to decide whether the symptoms and signs are due to lead poisoning. Traditional procedures, such as the administration of sodium bicarbonate, potassium iodide, parathormon, and vitamin $D$, to mobilize lead supplies in the human body and to increase urinary excretion have given poor results. We have found that $\mathrm{CaNa}{ }_{2} \mathrm{EDTA}$ is excreted more rapidly than PbEDTA. Experience in treating patients with chronic lead poisoning by means of $\mathrm{CaNa}_{2} \mathrm{EDTA}$ has shown this preparation to give much better results than the older methods. Several authors have considered the problem of how to effect the quantitative mobilization of lead for diagnostic purposes by means of this preparation (Rieders and Brieger, 1955; Teisinger and Srbová, 1956; Desoille, Albahary, Truhaut, and Boudene, 1957; Bastenier, Deslypere, and Mme. de Graef-Millet, 1957; Zahorski and Myslak, 1957). The work described in the present paper was undertaken to measure the urinary lead excretion after administering $\mathrm{CaNa}_{2}$ EDTA to normal and lead-exposed subjects, and to attempt to relate the amount of urinary lead excreted to the diagnosis of lead poisoning. 
TABLE 1

URINARY LEAD EXCRETION (MG.) IN 24 HOURS

\begin{tabular}{|c|c|c|c|c|}
\hline Group & $\begin{array}{l}\text { No. of } \\
\text { Cases }\end{array}$ & & $\begin{array}{l}\text { Before Injection of } \\
\mathrm{CaNa}_{2} \text { EDTA }\end{array}$ & $\begin{array}{l}\text { After Injection of } \\
\mathrm{CaNa}_{\mathbf{2}} \mathrm{EDTA}^{-}\end{array}$ \\
\hline $\begin{array}{l}\text { Normal } \\
\text { Exposed }\end{array}$ & $\begin{array}{l}50 \\
47\end{array}$ & $\begin{array}{l}99 \% \text { confidence limits of average value } \\
\text { Extreme values } \\
99 \% \text { confidence limits of average value } \\
\text { Extreme values }\end{array}$ & $\begin{array}{l}0.031<\bar{x}<0.043 \\
0.016<\overline{0} 0.099 \\
0.067<\bar{x}<0.082 \\
0.012<0.268\end{array}$ & $\begin{array}{l}0.143<\overline{\mathbf{x}}<0.153 \\
0.058<\overline{0} 0.352 \\
0.612<\overline{\bar{x}}<0.629 \\
0.166<-3.212\end{array}$ \\
\hline
\end{tabular}

Method

Two groups of in-patients at the Prague Clinic for Occupational Diseases were selected for the investigation. The first group of 50 patients had never been exposed to lead; the second group of 47 patients had worked with lead in various occupations (manufacture of lead paint, storage batteries, enamels, smelting, type casting). Each patient was given a single intravenous injection of $15 \mathrm{ml}$. of a $20 \%$ solution of calcium disodium ethylenediamine-tetra-acetate $(2 \cdot 8 \mathrm{~g}$. of anhydrous substance). The Czechoslovak preparation "edtacal, Spofa" was used as it had previously given good results. Urine was collected for 24 hours, for one to two days before injection and on the day after injection. The urinary lead content was determined by the method of Srbová and Teisinger (1957), in which the lead is precipitated as phosphate, dissolved in hydrochloric acid, and determined polarographically.

\section{Results}

The results are given in Table 1.

In both groups lead excretion was significantly increased following injection of $\mathrm{CaNa}_{2}$ EDTA.

On the day after injection the urinary lead was also significantly increased compared with that of the day before injection, but did not attain such high values. In the group of 50 people not exposed to lead the urinary lead did not exceed $0 \cdot 100 \mathrm{mg} . / 24 \mathrm{hr}$. before injection and $0.350 \mathrm{mg} . / 24 \mathrm{hr}$. after injection of $\mathrm{CaNa}_{2}$ EDTA.

Most of those exposed to lead had discontinued work with lead for several months-in some cases several years; only eight were still engaged in this work. Some of these cases had been sent to the clinic for investigation as it was known that they had worked with lead; others were suffering from unrelated illnesses. None of these patients had symptoms or signs of classical lead poisoning; the usual laboratory tests gave no results indicative of lead poisoning.

It was first established whether the urinary lead in the specimen collected on the day before injection varied from the values found in the urine of the $\mathbf{5 0}$ unexposed individuals. On the day before injection there $w$ as in fact a significant difference between the two groups (Table 1). The average value in the exposed group was within the confidence limits of $0.067<\overline{\mathrm{x}}<0.082 \mathrm{mg} . / 24 \mathrm{hr}$., with a probability of
$99 \%$, the extreme values obtained being 0.012 and $0.268 \mathrm{mg} . / 24 \mathrm{hr}$.

The difference between the two groups was also significant on the day of injection. The average in those exposed lay with a probability of $99 \%$ within the confidence limits of $0.612<\overline{\mathrm{x}}<0.629 \mathrm{mg}$. $/ 24$ hr., the extreme values being 0.166 and 3.212 mg. $/ 24 \mathrm{hr}$. On the day after injection there was also a significant difference between the two groups.

Thus it was proved that, following injection of $\mathrm{CaNa}_{2} \mathrm{EDTA}$, the average lead excretion of people working with lead rose markedly in comparison with those not exposed to lead.

Thirty-five individuals of the group exposed to lead were then examined by laboratory tests; stippled erythrocyte counts, blood lead, and urinary porphyrins were determined. In 28 cases lead mobilization by $\mathrm{CaNa}_{2}$ EDTA was positive; in the remaining seven cases lead mobilization was negative as the urinary lead values were below the limit of $0.350 \mathrm{mg}$. $/ 24 \mathrm{hr}$. In the group with positive lead mobilization urinary lead values varied from 0.415 to $3.21 \mathrm{mg} . / 24 \mathrm{hr}$. Stippled erythrocytes exceeding 1,000 per million red cells were present in $50 \%$ of these cases; plumbaemia above $0.070 \mathrm{mg}$. \% (this is the normal upper limit according to our polarographic method) was found in $50 \%$. The increased plumbaemia, however, did not always correspond to an elevated lead level in the urine. The number of cases with increased porphyrinuria (the normal upper limit was considered to be $0 \cdot 160 \mathrm{mg}$. $/ 24 \mathrm{hr}$.) was least, i.e., only $16 \%$. No relation between the results of laboratory tests and the mobilization of lead by $\mathrm{CaNa}_{2} \mathrm{EDTA}$ was therefore found. Most of these individuals had discontinued working with lead some months or years previously (nine of them had experienced clinical lead poisoning some years ago). This group, however, included two extreme cases of type casters who had discontinued working with lead 15 and 19 years previously, and, on injection of $\mathrm{CaNa}_{2}$ EDTA, excreted $0.415 \mathrm{mg}$. and $0.533 \mathrm{mg}$. respectively of urinary lead in 24 hours. Of the seven cases in which the lead mobilization by $\mathrm{CaNa}_{2} \mathrm{EDTA}$ was negative five were employees at a printing works. Four of these showed an increased number of stippled erythrocytes, from 1,700 to 
3,100 per million red cells; blood lead and urinary porphyrins were within normal limits.

The group of 47 lead-exposed individuals were suffering from various conditions; eight had symptoms of arteriosclerosis, 12 had affections of the lung such as silicosis (including lead-miners), emphysema of the lung, and tuberculosis; others were suffering from neurosis and diseases of the liver. Only two cases were suffering from chronic lead poisoning. In several cases of patchy disseminated lesions of the central nervous system and in two cases of polyneuritis a connexion with lead poisoning was suspected. In all cases of arteriosclerosis, which was found in older patients only, we rejected a connexion with lead poisoning despite a positive result for mobilization.

\section{Patients Suffering from Chronic Lead Poisoning}

In recent years, more than 120 patients suffering from chronic lead poisoning have been treated at the Occupational Diseases Clinic by means of $\mathrm{CaNa}_{2}$ EDTA. In all cases a considerable amount of lead was excreted on the day of injection. In order to determine whether there is any relation between the degree of poisoning and the amount of lead excreted after the first injection, we selected at random 10 cases of more serious lead poisoning (as evidenced by anaemia, colic, severe subjective symptoms, and high values in laboratory tests) and 10 slight cases showing a fall in haemoglobin. The laboratory tests (stippled erythrocyte count, blood lead, and urinary porphyrins) gave positive results in all 20 cases. It was found that lead excretion was considerably increased in the severer cases, amounting to values from $6 \cdot 2$ to $15 \cdot 2 \mathrm{mg}$. $/ 24 \mathrm{hr}$. In two cases, however, lead excretion attained only 1.36 and $1.74 \mathrm{mg}$., although clinically these two cases were as severe as the others.

In the group of slight or "laboratory" poisoning the urinary lead values varied around $2.5 \mathrm{mg}$. $/ 24 \mathrm{hr}$., but in two cases values as high as 7.32 and $8.92 \mathrm{mg}$. were found. These two individuals had no symptoms but all laboratory tests were definitely positive.

The degree of severity of lead poisoning seems therefore to be proportional to the urinary lead level after injection of $\mathrm{CaNa}_{2}$ EDTA. This rule, however, is not without exception, and a mere evaluation of the result of the first injection alone is not sufficient to estimate the severity of the lead poisoning.

\section{Lead Concentration Found by Fractionated Investigation of Urine}

In all the above cases the absolute amount of urine excreted in 24 hours was determined, which was practicable as all the individuals were detained

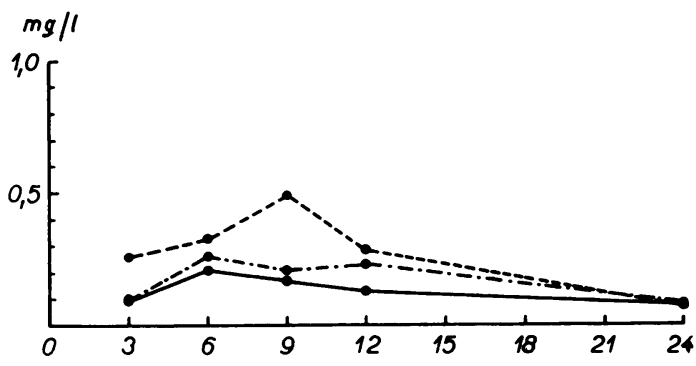

FIG. 1.-Lead concentration in the urine of unexposed individuals after intravenous injection of $3 \mathrm{~g}$. of $\mathrm{CaNa}_{2} \mathrm{EDTA}$.

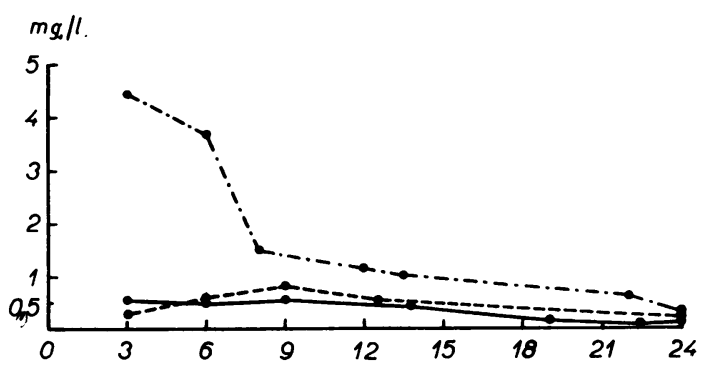

FIG. 2.-Lead concentration in the urine of individuals previously exposed to lead after intravenous injection of $3 \mathrm{~g}$. of $\mathrm{CaNa}, \mathrm{EDTA}$.

in hospital. This method is not suitable for outpatients as it is difficult to obtain the full amount of urine excreted in 24 hours. We therefore collected the urine from some further patients, three, six, nine, 12, and 24 hours after injection, determined the lead content and calculated the concentration per litre. The same dose of $\mathrm{CaNa}_{2}$ EDTA, 3 g., was injected intravenously as in the above cases. Some of the patients were given one litre of weak tea before injection.

In 10 individuals who had never been exposed to lead and had normal liver function tests, the lead concentration in none of the specimens exceeded $0.500 \mathrm{mg}$./litre. The maximum concentration was usually found six hours after injection, sometimes after nine hours (Fig. 1).

In four individuals who did not show any symptoms of lead poisoning but had formerly worked with lead, concentrations of $0.500 \mathrm{mg}$./litre and higher, up to $4.5 \mathrm{mg}$./litre, were found. The maximum concentrations were found at various time intervals (Fig. 2). In view of the small number of cases it was not possible to evaluate the relation between the amount of lead determined and the time elapsed since the termination of exposure, nor the severity of the hazard.

In seven patients with typical symptoms of chronic lead poisoning, higher urinary lead concentrations were found, irrespective of whether tea was given 


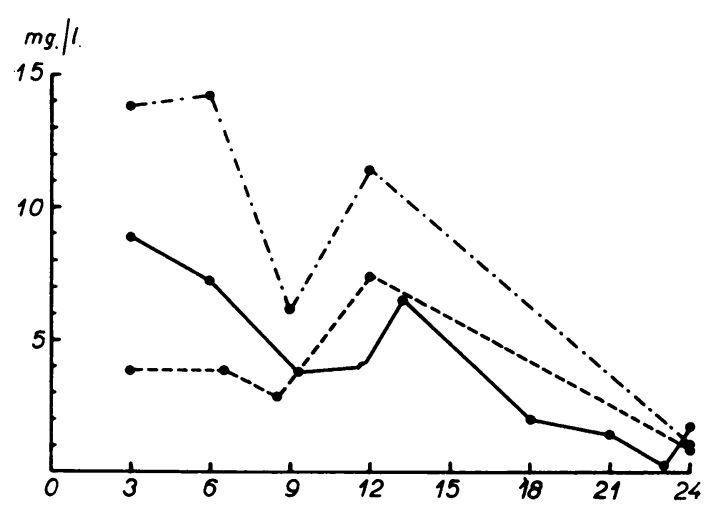

FIG. 3.-Lead concentration in the urine of patients suffering from chronic lead poisoning after intravenous injection of $3 \mathrm{~g}$. of $\mathrm{CaNa}$ EDTA.

before injection or not (three patients received tea and four did not). The maximum concentrations were found at differing time intervals, the highest value amounting to $21 \mathrm{mg}$./litre after six hours (without tea). In these cases the time of urine sampling was evidently of no importance, as all values were much above the normal limits (Fig. 3).

\section{Discussion}

The published data relating to normal lead content in human urine show considerable differences. In the U.S.A. a lead content of 0.01 to $0.08 \mathrm{mg}$./litre is considered normal (Kehoe, 1949). The Commission for Lead Poisoning of the American Public Health Association stipulated in 1943 that a lead excretion exceeding $0.150 \mathrm{mg}$./litre of urine indicated exposure to lead (Waldman and Seideman, 1950). In the U.S.S.R. values exceeding $0.06 \mathrm{mg}$./litre are considered as indicating slight poisoning (Lazarev, 1954). In our opinion these differences are partly due to the use of different analytical techniques but there is also a real difference. Different living conditions, food supplies, different lead content in soil and vegetables, must be taken into consideration. Based upon our previous experience and the results given in this paper, we consider that in Czechoslovakia an amount of $0.100 \mathrm{mg}$. of lead in 24-hour urine is to be considered the highest normal value. On an average, however, the values are much lower, i.e., 0.031 to $0.043 \mathrm{mg} . / 24 \mathrm{hr}$.

In the literature we could find few references to the absolute amount of lead excreted in 24 hours by normal individuals after injection of $\mathrm{CaNa}_{2}$ EDTA. Hardy, Elkins, Ruotolo, Quinby, and Baker (1954) found in three control individuals after intravenous infusion an increase from 0.09 to $0.65 \mathrm{mg} . / 24 \mathrm{hr}$. and less. Rieders and Brieger (1955) report that after intravenous infusion an amount of $1 \mathrm{mg}$. of lead/litre of urine (from a 24-hour sample) indicates increased deposition of lead in the body. A similar result, after intravenous infusion of $2 \mathrm{~g}$. $\mathrm{CaNa}_{2}$ EDTA, was obtained by Desoille et al. (1957), who gave a value of 0.8 to $1 \mathrm{mg}$. per litre of urine as indicating a positive result in this new test, although the amounts found in their three control cases did not exceed a concentration of $0.530 \mathrm{mg}$./litre. Thesc limit values seem high, but it is difficult to compare our results as different doses of $\mathrm{CaNa}_{2}$ EDTA were given. We have previously attempted to show (Teisinger and Srbová, 1956) that intravenous infusion gives somewhat better results than intravenous injection, which, however, is better suited to current practice. An intravenous injection of $1 \mathrm{~g}$. of $\mathrm{CaNa}_{2}$ EDTA was given by Salvini (1955) who concluded that normal individuals excrete up to $0.5 \mathrm{mg}$. of lead in 24 hours. In our opinion, after intravenous injection of $\mathrm{CaNa}_{2}$ EDTA, urinary excretion of lead in unexposed individuals does not exceed $0.350 \mathrm{mg} . / 24 \mathrm{hr}$. A dose of $3 \mathrm{~g}$. CaNa $\mathrm{CaDTA}_{2}$ was chosen because we had obtained satisfactory experience with this amount in the treatment of lead poisoning as well as for diagnostic purposes, but the possibility of a reduction of this dose is not excluded. It would, however, be necessary to re-examine the limit values if the dose were reduced. The method employed by us is, of course, intended for patients in hospital.

Bastenier et al. (1957) suggested a method suitable for out-patients. They administered $12 \mathrm{mg}$. per $\mathrm{kg}$. body weight of $\mathrm{CaNa}_{2}$ EDTA and determined the lead content in the urine three and six hours later. In 20 unexposed individuals the lead concentration in the urine after three hours did not exceed 0.300 $\mathrm{mg}$./litre. In our group of 50 people we observed a maximum concentration of $0.390 \mathrm{mg}$./litre, but the apparent agreement between these two figures is probably fortuitous, because we determined the total concentration in the urine after 24 hours and administered larger doses. In 10 further unexposed individuals we observed concentrations up to about $0.500 \mathrm{mg}$./litre not less than six hours after injection. This result was probably due to the larger dose of $\mathrm{CaNa}_{2}$ EDTA than that given by Bastenier et al. It is of little importance whether the limit value is given as $0.300 \mathrm{mg}$./litre or $0.500 \mathrm{mg}$./litre as the small lead deposits thus revealed are not likely to be of clinical significance. As the urinary lead concentration depends to a large extent on diuresis, it might be advantageous to give one litre of tea to the fasting patient,

Oral administration of $\mathrm{CaNa}_{2} \mathrm{EDTA}$ has also been employed for diagnostic purposes. Desoille et al. (1957) administered $4 \mathrm{~g}$. in two portions and gave 
an upper limit in unexposed persons of 0.500 mg./litre. They found that the level of urinary lead was not so high as after intravenous administration. $\mathrm{CaNa}_{2} \mathrm{EDTA}$ is only slightly absorbed by the alimentary tract; Foreman and Trujillo (1954) found $4 \cdot 2 \pm 2 \%$ absorbed, White (1953) found $1.5-4.5 \%$, while we found an average of $2.6 \%$ to be absorbed (Srbová and Teisinger, 1957).

The significance of diagnostic mobilization of lead may be considerable in cases in which latent saturnism is suspected, particularly in patients whose exposure to lead ceased some months or years ago. In such cases, diagnostic mobilization of lead may be a valuable aid to diagnosis: confirmation of the diagnosis is given by successful deleading treatment with $\mathrm{CaNa}_{2}$ EDTA.

In manifest cases of chronic lead poisoning diagnostic mobilization of lead is unnecessary. The clinical picture and laboratory tests are sufficient. Lead mobilization is of importance in deciding the method of treatment. We agree with Bastenier et al. (1957) that mobilization is useful for the control of deleading treatment.

The magnitude of the lead deposit which manifests itself by increased excretion after injection of $\mathrm{CaNa}_{2} \mathrm{EDTA}$ is related to the severity of the clinical picture, but exceptions corresponding to individual susceptibility are encountered. The magnitude of the lead deposit in the human organism required to cause positive laboratory tests or definite symptoms of poisoning is not known. There is at present no method available for determination of this critical magnitude. In treatment by means of complexforming substances the lead is flushed out mainly from the parenchymatic organs. The effect of $\mathrm{CaNa}_{2} \mathrm{EDTA}$ probably consists of speeding the spontaneous transference of the $\mathrm{Pb}^{++}$ions from cells into intercellular fluid by a disturbance in the equilibrium of this system. A direct effect on lead bonds in the cells appears less likely (Teisinger, Zumanová, and Žežula, 1958; Teisinger, Luštinec, and Srbová, 1958).

The question whether diagnostic mobilization of lead is of greater significance for the hygienist than biological tests cannot at present be answered as among our patients there were only a few who worked regularly with lead up to the time of examination.

The preparation BAL (2:3 dimercapto-propanol) has also been used for diagnostic mobilization of lead. Vigliani and Zurlo (1951) investigated urinary lead excretion following injection of BAL, and observed a considerable increase, especially in the first few hours after injection. The total amount excreted in 24 hours was on average 2.6 times that excreted before injection. Comparison of the values given by Vigliani and Zurlo in severer cases of lead poisoning with our results obtained after injection of $\mathrm{CaNa}_{2} \mathrm{EDTA}$ in cases of approximately the same nature showed BAL to be less efficient. Preda, Dinischiotu, Pilat, and Ionescu (1957) also observed mobilization of lead with increased excretion after injection of BAL. They concluded that the urinary lead concentration three hours after injection indicated the degree of the mobilizing effect. Their results also confirm our opinion that BAL is less effective than $\mathrm{CaNa}_{2}$ EDTA in increasing the urinary lead excretion.

We are greatly indebted to $\mathrm{Mg}$. Mat. Soňa Drdková for the statistical work.

\section{REFERENCES}

Bastenier, H., Deslypere, P., and Mme. de Graef-Millet (1957). Proc. 12 th Internat. Congr. Occup. Hth, Vol. III, p. 243, Helsinki 1st-6th July, 1957.

Desoille, H., Albahary, C., Truhaut, R., and Boudene, C. (1957).

Ibid., p. 287.
Foreman, H., and Trujillo, T. (1954). J. Lab. Clin. Med., 43, 566.

Foreman, H., and Trujillo, T. (1954). J. Lab. Clin. Med., 43, 566. Hardy, H. L., Elkins, H. B., Ruotolo, B. P. W., Quinby,

Kehoe, R. A. (1949). In Industrial Hygiene and Toxicology, ed. F A. Patty, Vol. II, p. 662. Interscience Publishers, New York.

Lazarev, N. V.' (1954), Vrednyje Vechestva v Promyshlennosti, Part II, Leningrad 1954, p. 440.

Preda, N., Dinischiotu, G. T., Pilat, L., and Ionescu, C. (1957). Arch. Mal. prof., 18, 145

Rieders, F., and Brieger, H. (1955). Proc. 7th Annual Meeting of the American Academy of Occupational Medicine, Phe American Academy of Occupar

Philadelphia, February 10th-12th, 1955.
Salvini, E. (1955). Folia med. (Napoli), 38, 168.

Salvini, E. (1955). Folia med.(Napoli), 38, 168. $15,572$.

Teisinger, J., Luštinec, K., and Srbová, J. (1958). A.M.A. Arch. industr. Hlth, $17,302$.

- , and Srbová, J. (1956). Arch. Gewerbepath. Gewerbehyg., 14 579.

—, Zumanová, R., and Žežula, I. (1958). A.M.A. Arch. industr. Hlth., 17, 295.

Vigliani, E. C., and Zurlo, N. (1951). Brit. J. industr. Med., 8, 218. Waldman, R. K., and Seideman, R. M. (1950). Arch. industr. Hyg., 1,

White, C. (1953). Cited by G. Maison (1953). A.M.A. Arch. industr. Hyg. $7,145$.

Zahorski, W., and Myślak, Z. (1957). Proc. 12th Internat. Congr. Occup. Hth, Vol. III, p. 242, Helsinki 1st-6th July, 1957. 